\title{
Face-to-Face Mirrors in the Iranian and Ottoman Constitution
}

\author{
Ahmad Jansiz ${ }^{1}$ \\ ${ }^{1}$ Political Science, University of Guilan, Rasht, Iran \\ Correspondence: Ahmad Jansiz, Department of Political Science, Faculty of Humanity, University of Guilan, \\ Rasht, Iran. Tel: 98-912-384-4835, E-mail: jansiz@guilan.ac.ir
}

Received: December 5, 2013 Accepted: March 8, 2014 Online Published: April 14, 2014

doi:10.5539/ach.v6n2p11

URL: http://dx.doi.org/10.5539/ach.v6n2p11

\begin{abstract}
Iran and Ottoman Empire, as two great powers with historical civilizations had mutual relationships for a long time. The constitutional era is of great importance in Iran-Ottoman foreign relations. The objective of the present study is to identify and assess the influences of political, social, economic and cultural conditions in Iran and the Ottoman Empire in constitutional era using a comparative approach. Reviewing the intellectual contexts of two neighboring communities and the presence of intellectuals and businessmen in both countries will aid further understanding of interactions as well as the causes of successes and failures of the Iranian and Ottoman constitution. Moreover, the concentration of written pro-constitution media in Istanbul and the special attention of Ottoman government to Iranian revolutionaries, activities of Iranian political communities in Anatolia and Istanbul, the role of embassies of two countries, the efforts made by Muslim intellectuals and scholars in both territories were effective in development of a comprehensive constitution during the rise and fall of the Ottoman and the Iranian constitution. Iran and the Ottoman had common enemies during constitutional era. They were involved with political, cultural, military and bureaucracy challenges in modernization process. However, they assumed their mirages real in their face-to-face mirrors. The present study reviews the similarities and differences between Iranian and Ottoman constitution using desk study method. It evaluates descriptively and analytically the influence of events and political currents of constitutional era as well as the political mirage caused by various factors of constitutional revolution on political and religious leaders of both countries.
\end{abstract}

Keywords: constitution, modernization, Iran, ottoman, tradition, modernity

\section{Introduction}

About 200 years ago, political ideas against the absolutist state were formed in Ottoman lands. The intellectuals who were familiar with western, particularly European political thoughts, inspired by the new ideas of the West and thought about the confinement of political governance of monarchy system. An article published in Hurriyet newspaper in 22 May 1870 entitled "The difference between republic system and self-governance" which reflects this type of opinion among the Ottoman community. According to this article, "There is a parliament in the republic system which its members are elected by people. Namely, the wisest and most patriot representatives are elected for a certain period. The individuals are free and independent in their own civil rights" (Ebüzziya, 1973).

However, with the spread of modern ideas in the West, the Ottoman power was declined such that it was described by westerners as "sick man" in its late life. Although the Ottoman political elite made their best to prevent the decline of this Muslim power and experienced different ways from imitation of the West, to the political, military, economic and cultural reforms, neither imitating the West nor rapid modernization of the Ottoman Empire neither the pan-Turkism nor Islamism could save the country from this deadly trend. In this period, Iran, the eastern neighbor of Ottoman Empire had experienced a similar fate. Both countries faced with similar problems. The Ottoman community was familiar with reforms naturally earlier than Iran. Political changes in the Ottoman community had a large impact on the constitutional processes in Iran. Reviewing these effects demonstrates the important role of intellectuals and intelligentsia in the constitutional revolution in Iran. During this period, Ottoman territory was a bridge between Iran and Europe. Therefore, the present article largely aims to study the effect of Ottoman constitutional scheme on Iranian constitution.

\section{Origins}

Constitutional theory is rooted in the 18th century. With the decline of the kingdom and development of an 
autonomous administration that served the interests of the state as well as the development of the ideas of popular and national sovereignty, a different interpretation of the nature of government was needed. The first and strongest state theory in the European thinking history was the theory of the Constitution which is considered as the foundation of the large part of thinking about the government to present (Wincent, 1987). The face-to-face mirrors in the Iranian and Ottoman Constitution reflect the maturity of constitutional thought and political mirage within these two communities. Undoubtedly, the study of the influencing both Muslim communities and neighbors from their political fates needs a comparative perspective toward the political, cultural and social conditions in these two countries. First of all, although there were some clashes between Ottoman Sunni and Safavid Shia in earlier times, no friction has taken place between two governments and nations during the constitutional era.

The first Ottoman Constitution won in 1876. It lasted only two years. The "Young Ottomans" had a critical role in declaring the First Ottoman Constitution. This organization was founded in 1865. According to the first constitution, while legislative competence belonged to the Parliament, the monarch would have the last word. The king also had an unlimited veto right. According to this constitution, the Head of state and ministers was selected by the king. King had the authority to shut down Parliament. Furthermore, the executive authority has been divided the king and government. The king has the authority to propose new legislation. No one could form a party or community or hold a rally. War and peace conclusion was granted to the king. During his reign, King Abdul Hamid II supported the Ottoman-orientation, Muslim unity and Islamist policy to preserve the Ottoman Empire. Thus, he looked at constitutional tendencies with suspicion. While the Islamic intentions were observed among the Iranian constitutional scholars and Muslim intellectuals, the role of Turkish intellectuals like Zia Pasha, Ahmed Medhat, Mustafa Fadel Pasha, Ali Saavy and Namegh Kamal was impressive in the first Ottoman constitution. The role of the Ottoman constitutional scholars was lower than the Iranian scholars.

In the second Ottoman constitution in 1908, a year after the Iranian Constitutional Revolution, conditions were identical. The second constitution lasted 12 years. The "Union and Progress" organization declared constitution. Intellectuals like Abdullah Jawdat, Enver Pasha, Cemal Pasha, Hassan Tuson and Ismail Canpolat led the movement. The second Ottoman constitution was adopted in 1909 and the conditions were changed. King had not the authority to shutdown Parliament (Browne, 1966). Also, the king was deprived of veto right. The government was accountable to the Parliament. Only Parliament could offer only new laws. According to the new constitution, people had the right to form a political party or community. They could, if necessary, make the protests. Furthermore, parliamentary approval was required for the conclusion of peace and war. Studies indicate that the constitution of the first Iranian constitution was superior to the first Ottoman constitution (Bayat, 1991). However, the interval of the preparation of these two documents should be considered. However, there are many similarities in the form and content of both texts. The time of events indicates the impact of political changes in the two countries on each other.

\section{The Role of Intellectuals}

Everyone knows that the intellectuals have a very important position in political developments and changes like reform movements and revolutions. This fact is confirmed by political and social developments in Iran and throughout the world. Although intellectuals do not consider themselves as politicians, they indirectly influence on policy through stimulating the social and cultural roots of issues (Soroush, 1998). These professional intelligent are numerous and more free. Furthermore, they have become closer to the center of power in the current century. Intellectual, either writer or artist is a man of thought. The intellectual contributes to faith in human and thought. Intellectuals go beyond the framework of traditional in every field. They create new values or cover a new cloth to traditional values. Intellectuals offer new ideas to explain various aspects of life. They solve practical problems by utilizing the thinking and critical power. Intellectuals create new philosophies for living and come out the loop of current frameworks of thought, culture, science and art. Despite the obstacles around them, intellectuals of any country have following crucial features in the society:

Creating new ideas, going beyond common traditions and contexts of thought, interest to the public good, continuous intellectual labor as the main profession, criticizing social and political status quo, no affiliation to a specific class interests, addressing the disposition and political ideologies, offering new "lifestyles", reasoning in community affairs, politics and culture, awareness of the conflicts and struggles over political power, creation and transmission of culture, creating social theories, relation to the subjective dimension of social life against its productive and objective dimension, symbolic presentation of the social interests of the ruling and non-ruling classes, backing to folk traditions, guiding the society toward the rightful wishes and interests of the community against ordinary and transient aspirations, dissatisfaction with the status quo, identifying main problems and conflicts in society and providing solutions and predicting the future pathway, rethinking, interest in general and 
abstract issues, social pathology against "being scientists" in the traditional sense and cynicism and distrust of those in power (Bashiriyeh, 1995)

\section{The Role of Intellectuals in Iranian and Ottoman Constitutions}

Undoubtedly, Ottoman and Iranian intellectuals played an important role in formation and growth of reform ideas in their community. This educated class had several impacts in constitutional era including criticizing the existing political system, participation in political and cultural activities, informing the masses and leading them towards a brighter tomorrow. Ottoman intellectuals often monitored political developments in Europe. Ottoman land was a bridge between Europe and Iran (Bonakdarian, 2006). Thus, the political implications on confinement of the monarchy system and increased public participation in major decisions were generally moved from Europe to the Ottoman Empire. The interactive relationship of Iranian and Ottoman intellectuals had great impacts on the people of both countries and spread a new political language among the masses (Brummett, 2000).

On the other hand, the internal situation in Iran and the Ottoman Empire gave momentum to the reforms and constitutional ideas. Iranian constitutionalists' spirit went up after the success of the Ottoman constitutional movement. Iranian activists in Istanbul and other Turkish cities established contacts with Turkish leaders. Through this, they were intimately familiar with recent political events. Iranian intellectuals and statesmen used the experience of the Ottoman constitutional and increased their political and reform demands. Jamaluddin Asadabadi met with Iranian fighters in Istanbul and led activities against the Iranian regime. The culmination of these influences was assassination of Iranian Shah by supporters of Asadabadi. Hussein Vassaf, one of Sufi sheikhs in Ottoman constitutional era believed that Jamaluddin collaborated with the "Young Turks" and had meetings with Iranian revolutionaries (Kara, 2003). AmirKabir resided for about four years in Erzurum and witnessed the Ottoman reforms (Raeesnia, 1995). After inspiring for founding Dar-ol-Fonon, AmirKabir became more determinants for publishing internal and external publications and making diversity in the Iranian press.

Mirza Hossein Khan Sepahsalar was the Iranian minister in Istanbul for fourteen years. He had close relations with the leaders of the "Union and Progress". After returning to Iran, Sepahsalar became the Minister of Justice. He could do significant reforms in this ministry. Given his special attention to the command of the Ottoman settings, he made vast reform in the course of his chancellery. Sepahsalar played a noteworthy role in transferring implications such as the rule of law, development of the West, public interest, nation vote, civilization and modernization to Iran. He could make a position for these concepts in official documents by his reports. These reports were effective in spreading reformist thoughts among the Iranian bureaucrats. But because of his special attention toward the Ottoman reforms, he was considered as an imitator of the Ottoman state (Ajoodani, 2008). Another character impressed by Ottoman reform was Mirza Yusuf Khan Mostashar-Al-Doleh. When resided in France as an Iranian diplomat, he found a chance for evaluating reformist ideas of Ottoman intellectuals. During Ottoman constitutional era, Istanbul and Anatolia hosted other personalities and intellectuals including AbdulMalik, Abbas Mirza Molk Ara and also Khabir-Al-Molk. They continued their political activities impressed by the ideas of Ottoman intellectuals (Keddie, 1999).

During the Ottoman constitutional era, Istanbul was the center of preparation, compilation and distribution of publications of political activists who have come from Iran. Nowadays, although this city is not the capital of Turkey, it is considered as the most important political, cultural and media center in Turkey. Iranian immigrants, refugees or exiles rarely had been faced with restrictions during their political career. In this regard, the Mirza Abdul-Rahim Talibov work entitled "Ahmad" is also noteworthy. It is interesting that the intellectual tendency of Talibov about the modernity and civilization was also popular among the Ottoman Muslim intellectuals. Another work entitled "A Journey of Ibrahim Beyk" was written by Zayn Al-Abedin Maraghei, an Iranian businessman who was traveling to Istanbul. Furthermore, the young Iranian intellectuals published a newspaper entitled "Akhtar" in Istanbul. Two journalists named Mirza Mahdi and Mohamed Tahir were the publishers of this newspaper. Akhtar published some articles of Zayn Al-Abedin Maraghei and Mirza Aqa Khan Kermani. The newspaper was smuggled into Iran. It had a lot of readers in different countries.

Another Iranian intellectuals who drawn the Ottoman statesmen was Malcolm Khan. He long lived in Ottoman society which coincides with the second Ottoman constitutional era. He witnessed political and reform upheaval in Ottoman territories. Malcolm Khan believed that the fate of Iran and Ottoman is as chain loops which are connected by a thousand means (Abrahamian, 1982). Malcolm Khan sent his newspaper "Ghanoon" through Istanbul to Iran. Some Turkish writers believed that the relationship between the followers of Bob and Ottoman constitutionalists is more serious than Malcolm Khan's contacts with "neo-Ottoman" (Mardin, 1983: 54). On the other hand, the "Welfare Community" continued its political activities in Istanbul with the help of Turkish 
intellectuals. During Ottoman constitutional era, the Iranian constitutionalists received the contributions from this community for many years. In this regard, the "Welfare Community" was one of the most influential organizations opposing the Iranian monarchy in Istanbul (Gheisari, 2005). Also, a guest intellectual was present in Iran as the Ottoman's ambassador to Iran who helped the Iranian constitutionalists. Muhammad Shams al-Din Beyk had a very close relationship with the leaders of the Iranian constitutional revolution. He constantly encouraged Iranian constitutionalists.

The influence of Ottoman constitution on Iranian constitution and vice versa was originated from common reasons in both communities. Both countries were confronted with Western modernity and governments had been found in the fall (Afary, 1996). Also, the followers of traditional Islam in that period had failed to respond to the contemporary issues. Although, the intellectuals in both countries were sensitive to their fates, they considered the success of the constitutional movement in their neighbor as their own success, and tasted the same broken. The life of constitutionalism was short because of very bitter reasons. The secular intellectuals of "Union and Progress" in Ottoman state led the government into the great wars and misery. Said Halim Pasha, one of the intellectuals in constitutional era believes that this misery is due to the blind imitation of the West (Kara, 1986). In Iran, the required collaboration was not established between constitutional scholars. On the other hand, the movement lacked a charismatic leader. It cannot be said that the Iranian and the Ottoman constitution have failed. Undoubtedly, the access of Iranian to the Islamic Republic of Iran after the revolution in 1978 is influenced by the constitutional movement. The republic system was established in Turkey, but the Turkey lacked a democratic society for several decades. Nowadays, there is an interactive relationship between Islamist and secular intellectuals, a relationship which seems very difficult to establish in contemporary Iranian society in the near future.

Turkish Muslim intellectuals do not like the modernist intellectual, Akhundzadeh, when surveying Iranian constitutional history. Obviously, this was due to his insistence on changing the line to access modernity. Akhundzadeh wrote in a letter to Malcolm Khan "The Ottoman government opposes modified alphabets, because their despot reign and religion will destroy following the implementation of the new alphabet and dissemination and promotion of sciences. It is obvious that following dissemination and promotion of sciences, despotism, phantasm and superstition will not remain" (Qazi Moradi, 2006). Although this work was done in 1928 by Mustafa Kemal Ataturk, Turkey has not come to the Western civilization level after eight decades. Turkish Muslim intellectuals also do not trust in the westerner Malcolm Khan. They accept Islamist Jamaluddin with caution, while they iteraction-oriented intellectuals like Talibov. Now it can be argued that Turkish intellectuals care about the fate of the Iranians more than Iranian intellectuals caring about the fate of Turkish population. While the political and cultural cooperation between the two neighboring Muslim peoples in the region and on the international scene seems smoother than the constitutional era, undoubtedly the value of cultural cooperation is more and effective than diplomacy.

\section{Conclusion}

Iranian and Ottoman political elites and intellectuals were influenced by their reformist developments in the constitutional era. The source of modernity breeze was the West. Ottoman society played a role of bridge between the West and Iran. The presence of intellectuals, political figures, businessmen, media and refugees opposing the Iranian government in the Ottoman state and their cultural and political activities in Ottoman cities, especially Istanbul transferred the political language of reform wave and constitutional philosophy to Iranian community. Although both Iranian and the Ottoman constitution fated a dead-end, it can be said that the constitutional movement never left disappointed and it has added lessons on political experience of two neighboring communities. Increased democratic tendency in Turkey and Iran indicates this fact that republic system was established after some time in both countries. Turkish achieved the republic system before Iranian and formed a secular republic in Turkey. Their compass was the West and now they are trying to join the Europe Union. In contrast, Iranian preferred "Islamic Republic" system and mainly focused on "opposition with powers and interaction with Islam World". Despite some rise and fall in the relations of two neighboring countries, political, economic and cultural developments are in progress in both countries in a reformist fashion.

\section{References}

Abrahamian, Y. (1377). Iran Beyne Do Enghelab. Tarjomaye Ahmad Gol Mohammadi, Tehran: Nashre Nay.

Afary, J. (1996). The Iranian Constituonal Revolution, 1906-1911. New York: Colombia University Press.

Ajoodani, M. (1387). Mashruteye Irani. Tehran: Akhtaran.

Bashiriyyeh, H. (1374). Jamee shenasi Siasi. Tehran: Nashre Nay. 
Bayat, M. (1991). Iran's First Revolution. New York: Oxford University Press.

Bonakdarian, M. (2006). Britain and the Iranian Constituonal Revolution of 1906-1911. Foreign Policy, Imperialism and Dissent (Modern Intellectual and Political History of the Middle East), Syracuse University Press.

Browne, E. (1966). The Persian Revolution of 1905-1909. London: Frank Cass.

Brummett, P. (2000). Image and Imperialism in the Ottoman Revolutionary Press, 1908-1911. New York: Suny Press.

Ebüzziya, T. (1973). Yeni Osmanlılar Tarihi. İstanbul: Kervan.

Geisari, A. (1384). Roushanfekrane Iran dar Qarne Bistom. Tarjomaye Mohammad Dahghani, Tehran: Harmas.

Güneş, İ. (2012). Meşrutiyetten Cumhuriyete Türkiye'de Hükümetler, Proğramları ve Meclisteki Yanklları (1908-1923). Ankara: Türkiye İş Bankası Kültür Yayınları.

Kara, İ. (1986). Türkiye'de İslamcllık Düşüncesi. 1. Cilt, İstanbul: Risale.

Kara, İ. (2003). Din İle Modernleşme Arasında. İstanbul: Dergah,.

Keddie, N. (1999). Qajar Iran and the Rise of Reza Khan, 1796-1925. Costa Mesa, California: Mazda Press.

Mardin, Ş. (1983). Jön Türklerin Siyasi Fikirleri 1895-1908. İstanbul: İletişim.

Qazi Moradi, H. (1385). Novsaziye Siasi dar Asre Mashruteye Irani. Tehran: Akhtaran.

Raeesnia, R. (1374). Iran va Osmani dar Astaneye Qarne Bistom. Tabriz: Setudeh.

Soroush, A. (1377). Razdani va Roushanfekri va Dindari. Tehran: Serat.

Wincent, A. (1376). Nazariyyehaye Dovlat. Tarjomeye Hossain Bashiriyyeh, Tehran: Nashre Nay.

\section{Copyrights}

Copyright for this article is retained by the author(s), with first publication rights granted to the journal.

This is an open-access article distributed under the terms and conditions of the Creative Commons Attribution license (http://creativecommons.org/licenses/by/3.0/). 